\title{
Madrasah: dari Nizạāmiyyah hingga Pesisiran Jawa
}

\author{
Mahfud Junaedi \\ Institut Agama Islam Negeri Walisongo Semarang \\ Email: mahfud_junaedi79@yahoo.com
}

\begin{abstract}
Growth and development in the Coastal Java madrasah in the early twentieth century until now generally spearheaded by scholars/religious leaders who graduated in Islamic centers in the Middle East. At first they established the boarding school, followed by the establishment of madrasah to the coast of Java can be regarded as children of a boarding school. The educational institutions have bonding formation of madrasah was first built by Nizam al-Mulkin Baghdad in 1057, later known as madrasah Nizamiyah. This school is an educational institution that aims to teach Fiqh Sunni schools. Institutions of higher education has become one of the eleventh century and became the blueprint for the development of similar madrasah in the Islamic world. Historically, madrasah in Java can not be separated from the Middle East, especially the relationship Haramayn scholars of al-Azhar and Cairo with the students in Java, Indonesia.
\end{abstract}

Keywords: madrasah, Coastal Java, Madrasah Nizamiyah, scholar

\begin{abstract}
Abstrak
Pertumbuhan dan perkembangan madrasah di Pesisir Jawa pada awal abad keXX hingga kini, umumnya dipelopori oleh para kiai atau tokoh agama yang menamatkan pendidikan di pusat-pusat Islam tersebut. Pada awalnya mereka mendirikan pondok pesantren, lalu diikuti dengan pendirian madrasah, sehingga madrasah di pesisir Jawa bisa dikatakan sebagai anak-anak pesantren. Lembaga pendidikan ini memiliki ikatan dengan madrasah pertama kali dibangun oleh Nizam al-Mulk di Baghdad pada tahun 1057, kemudian dikenal dengan madrasah Nizamiyah. Madrasah ini merupakan lembaga pendidikan yang bertujuan untuk mengajarkan fikih mazhab Sunni. Lembaga pendidikan tinggi ini ada pada abad kesebelas dan menjadi cetak biru bagi pengembangan madrasah-madrasah serupa di dunia Islam. Secara historis, keberadaan madrasah di Jawa tidak dapat dipisahkan dari hubungan ulama Timur Tengah, khususnya Haramayn dan alAzhar Kairo dengan para murid di Jawa, Indonesia.
\end{abstract}

Kata kunci: madrasah, pesisir Jawa, madrasah Nizamiyah, ulama. 


\section{A. Sejarah Madrasah di Dunia Islam}

Keberadaan madrasah di pesisiran Jawa, tentunya tidak bisa dipisahkan dari sejarah keberadaan madrasah di dunia Islam pada umumnya. Maka dalam tulisan ini akan diuraikan terlebih dahulu tentang sejarah madrasah di dunia Islam secara sekilas.

Para ahli sejarah pendidikan Islam hingga saat ini belum menemukan kata sepakat tentang kapan dan di mana madrasah pertama kali didirikan. Pertama, sejarawan pendidikan Islam ternama, Ahmad Syalabi berpendapat bahwa madrasah yang pertama kali didirikan di dunia Islam adalah Madrasah Nizamiyah di Baghdad, madrasah ini didirikan oleh Nizam al-Mulk (w. 485 H/1092 M), menteri pendidikan dari Sultan Alp Arslan dan Mālik Syah (era kekuasaan Bani Saljuk), dengan tujuan untuk mengajarkan agama, khususnya Islam Sunni, sebagai upaya untuk mengikis ajaran Syiah yang berkembang di tengah-tengah masyarakat muslim pada waktu itu $^{1}$.

Pendapat tersebut didukung oleh al-Maqrizi, sebagaimana dikutip oleh Makșum, menjelaskan bahwa madrasah merupakan prestasi abad kelima Hijriah. Menurutnya, madrasah belum dikenal pada masa sahabat dan tabi'in, melainkan sesuatu yang baru dikenal setelah abad keempat Hijriah ${ }^{2}$. Senada dengan Syalabi adalah Mehdi Nakosteen dan Michael Stanton, menurutnya madrasah yang didirikan oleh Nizam al-Mulk merupakan institusi pendidikan dalam bentuk baru (a new type of school) yang pada era sebelumnya belum ada. ${ }^{3}$ Madrasah juga merupakan institusi pendidikan par excellent di dunia Islam. Demikian halnya George Maqdisi, dan Hiṣam Nasambe, serta sejarawan Philip K Hitti, menegaskan bahwa madrasah merupakan evolusi dari lembaga pendidikan Islam sebelumnya yaitu Kuttab atau Maktab, masjid dan masjid Khan, yang pada umumnya diasosiasikan kepada perdana mentri Nizam al-Mulk, ini disebabkan keberhasilannya dalam mendirikan madrasah Nizamiyah di Baghdad pada tahun antara 457 dan 459 H. (1065

${ }^{1}$ Ahmad Syalabi, Sejarah Pendidikan Islam (Tarikh al-Tarbiyah al-Islāmiyah), terj. Muchtar Jahja, dan Sanusi Latief, (Jakarta: Bulan Bintang, 1973), hlm. 109-110.

${ }^{2}$ Maksum, Madrasah Sejarah dan Perkembanganya, (Jakarta: Logos Wacana Ilmu, 1999), hlm. 60.

${ }^{3}$ Mehdi Nakosteen, History of Islamic Origins of Western Education AD. 800-1350, With an Introduction to Medieval Muslim Education, (Colorado: University of Colorado Press, 1964), hlm. 38-40. 
dan $1067 \mathrm{M}$ ), dan selanjutnya mempopulerkan madrasah dengan cara mendirikan banyak madrasah lain yang serupa di Iraq. ${ }^{4}$ Madrasah Nizamiyah merupakan prototipe madrasah dalam peradaban Islam, merupakan lembaga pendidikan resmi dan pemerintah terlibat dalam menetapkan tujuan pendidikannya, menentukan kurikulumnya, memilih guru, dan memberikan subsidi finansial kepada madrasah. Bahkan madrasah Nizamiyah merupakan lembaga yang menghasilkan pegawai-pegawai pemerintah.

Ketenaran madrasah Nizamiyah, dibandingkan dengan madrasah-madrasah lainnya, menurut Michael Stanton disebabkan karena madrasah ini menjadi salah satu lembaga pendidikan yang sangat dikenal pada abad kesebelas, dan menjadi cetak biru (blue print) bagi pengembangan madrasah-madrasah serupa di dunia Islam. Selain itu, para ilmuwan hingga saat ini dapat lebih memahami keberadaannya, karena ketersediaan dokumen tentang pendirian dan perkembangannya ${ }^{5}$.

Joseph S. Szyliowicz, juga menegaskan bahwa meskipun madrasah telah berdiri pada awal abad ke-9 M, namun madrasah yang menjadi model sistem pendidikan madrasah keseluruhan, adalah madrasah Nizamiyah yang dibangun oleh Nizam al-Mulk di Baghdad pada tahun 1057M. Kemashuran madrasah ini telah meluas dan merangsang pertumbuhan madrasah yang sama juga dapat diterima oleh masyarakat luas (universal accepted) di dunia Islam ${ }^{6}$. Setelah madrasah dikembangkan oleh Nizam al-Mulk, madrasah menyebar di Iraq, Khurasan, al-Jazira dan kota-kota lain di dunia Islam. ${ }^{7}$ Szyliowicz juga menuturkan bahwa pembangunan madrasah Niẓamiyah sangat mendorong berdirinya madrasah-madrasah lainnya, di Kairo berdiri lebih dari 75 madrasah, dan 86 madrasah

${ }^{4}$ George Maqdisi, The Rise of Colleges; Institrutions of Learning in Islam and The West, (Edinburgh: Edinburgh University Press, 1981), hlm. 147. Baca pula: Hisham Nashabe, Muslim Educational, hlm. 23., dijelaskan oleh Nashambe bahwa: "al-Madrasah al-Nizamiyah of Bagdad is particularly important in the history of Muslim Education".

${ }^{5}$ Charles Michael Stanton, Higher Learning in Islam, Clasical Period AD. 700-1300, (Maryland: Rowman \& Littlefield Publisher Inc., 1990), hlm. 40 .

${ }^{6}$ Joseph S. Szyliowicz, Education and Modernization in The Midle East, (London: Cornell University Press, 1973), hlm. 63.

${ }^{7}$ John L Esposito, The Oxford Encyclopedia of the Modern Islamic World, (Oxford: Oxford University Press, 1995), hlm. 13. 
di Damaskus, dan 51 madrasah di Aleppo. Sistem madrasah mencapai puncaknya pada zaman kekhalifahan Turki Ustmani.

Berbeda dengan pendapat pertama tersebut, Richard W Bulliet menjelaskan bahwa dua abad sebelum madrasah Nizamiyah didirikan oleh wazir Nizam al-Mulk, di Nishapur telah berdiri madrasah Miyān Dahiyā dengan tokoh kunci mudarris dan jurist Abu Ishaq Ibrahim bin Mahmud bin Hamzah (w. 270 atau $314 \mathrm{H}$ ), yang merupakan pengajar hukum mazhab Maliki. ${ }^{8}$ Selain madrasah Miyān Dahiyā, Bulliet menegaskan secara kronologis telah berdiri 37 madrasah lainnya di Nishapur, di antaranya madrasah Abū alHasan 'Ali aṣ-Ṣibgi (w. 305 H), madrasah Abū al-Walīd al-Qurașī (w. 349 H), madrasah Abū Ișāq al-Basțāmī (w. 314 H), madrasah Ibn Fürak (372 H), dan lain sebagainya.

Senada dengan Bulliet, Hasan Abd al-Al berpendapat bahwa madrasah telah berdiri sejak abad keempat Hijriah. Untuk memperkuat pendapatnya Abd al-A'la mengutip beberapa kitab yang ditulis oleh para ulama abad keempat, di antaranya Ahsan alTaqāsim fi Ma'rifat al-Aqālim karya al-Maqdisi (w. $378 \mathrm{H}$ ), Ţabaqāt al-Syafi'iyyah al-Kubrā karya al-Subkhi (w. 388 H), dan al-Rasāil karya Badi' al-Zaman al-Hamadani (w. 389 H). ${ }^{9}$ Namun Abd al-A'la tidak menyebut nama madrasah apa yang sudah berdiri sebelum madrasah Nizamiyah.

Para ahli sejarah pendidikan Islam mencatat bahwa, abad kelima Hijriah (11M) dilihat sebagai saat yang menentukan (turning point) sejarah perkembangan madrasah di dunia Islam. Madrasah yang sebelumnya merupakan lembaga swasta, yang sangat personal dan mandiri, berubah menjadi lembaga pendidikan resmi pemerintah dan bersifat sangat politisi. Madrasah yang pada awalnya tidak memiliki misi khusus untuk menyerang paham atau aliran lainnya, sejak berdirinya madrasah Nizamiyah berubah menjadi sebaliknya. Hal ini bisa dipahami karena madrasah Niẓamiyah

\footnotetext{
${ }^{8}$ Richard W. Bulliet, The Patricians of Nishapur, a Study in Medieval Islamic Social History, (Harvad: Harrvad University Press, 1972), hlm. 48, 249. Bulliet menulis, The name of Miyān Dahiyā is Persian and means "middle of the village" suggesting a nonurban location. It should be noted that chronologically this madrasah antedates both al-Azhar in Cairo and the flourishing of Karrāmiya sect, both of which have been suggested as models of the Sunni madrasah.

${ }^{9}$ Hasan Abd al-A'la, al-Tarbiyah al-Islāmiyah fí al-Qarn al-Rabi' al-Hijri (Cairo: Dār al-Fikr al-Arabi, 1978), hlm. 210.
} 
didirikan dengan tujuan untuk mengajarkan paham Sunni dan membendung berkembangnya paham Syi'ah di dunia Islam.

Adapun tentang tempat di mana pertama kali madrasah tumbuh, Ira M. Lapidus menulis bahwa, madrasah sebagai sebuah perguruan yang diorganisir secara formal diduga berasal dari Khurasan, karena di sinilah hukum Islam (Syari'ah) diajarkan di rumah-rumah pribadi, yang kemudian disediakan tempat menginap bagi para guru dan pelajar yang datang dari jauh. Madrasah di Baghdad, kemudian diorganisir menjadi sebuah lembaga pendidikan resmi pemerintah.

Baik pendapat Bulliet maupun Abd al-A'la ini tidak banyak mendapat dukungan dari para sejarawan pendidikan Islam saat ini. Hal ini mungkin disebabkan karena madrasah yang muncul sebelum berdirinya madrasah Nizamiyah, bersifat eksklusif karena untuk kalangan para bangsawan (patrician), dan belum terorganisir secara rapi dan tertib, serta masih menjadi satu dengan rumah pendirinya, masjid atau masjid Khan.

Terlepas dari masalah kapan dan di mana pertama kali madrasah muncul di dunia Islam, hal lain yang juga sangat penting untuk diungkap adalah motif apa yang sebenarnya melatarbelakangi para penguasa muslim atau para tokoh lainnya mendirikan institusi madrasah. Berikut ini akan dijelaskan motif-motif pendirian madrasah di dunia Islam.

Pertama, motif politisi. Karena keberadaan madrasah tidak terlepas dari kekuasaan, yakni madrasah dijadikan sebagai instrumen untuk melanggengkan kekuasaan, dan tidak semata-mata didorong oleh kesadaran akan pentingnya ilmu pengetahuan bagi masyarakat muslim. Hal ini, diakui oleh Syalabi, Nakosteen, Szyliowicz dan juga Maqdisi bahwa madrasah-madarash yang dibangun oleh Nizam al-Mulk, memiliki tujuan politik dan agama, untuk membentuk opini publik Islam Sunni ortodoks terhadap Islam Syi'ah, selain juga memiliki spirit ilmu pengetahuan yang tinggi. Hal ini dapat dipahami karena musuh yang dihadapi oleh Dinasti Saljuk yang Sunni ini adalah Dinasti Fatimiyah di Mesir yang beraliran Syi'ah, dan salah satu upaya perlawanan yang efektif untuk melawan ideologi Syi'ah adalah dengan mendirikan lembaga pendidikan, dalam hal ini madrasah Nizamiyah. Pertimbangan ini perlu dilakukan karena Syi'ah sangat aktif dan sistematik dalam melakukan indoktrinisasi melalui pendidikan atau aktivitas 
pemikiran yang lain. ${ }^{10}$ Diakui oleh para sejarawan, bahwa madrasah dalam hal ini dijadikan sebagai media artikulasi politik bagi penguasa.

Kedua, motif profesional atau administratif dan ekonomi serta motif sosial. Pada awal keberadaannya, institusi madrasah didirikan sebagai kelanjutan dari masjid dan masjid Khan. ${ }^{11}$ Hal ini disebabkan karena, pembelajaran yang diberikan di tempat-tempat tersebut memiliki beberapa keterbatasan. Kurikulumnya terbatas dan tidak selalu memiliki guru-guru yang baik, fasilitas fisik bukan lagi untuk lingkungan pendidikan yang memadai. Selain itu pertentangan antara tujuan pendidikan dan tujuan agama di dalam masjid hampir tidak dapat diperoleh titik temunya. Tujuan pendidikan, di satu sisi, menghendaki adanya bermacam-macam aktivitas sehingga menimbulkan keramaian, dan hiruk pikuk. Sedangkan di sisi lain yakni beribadah di masjid, menghendaki ketenangan dan kekhusyukan. Berikutnya, faktor eksternal yang juga mendukung dikembangkannya madrasah adalah adanya kenyataan, bahwa kemajuan dan penyebaran ilmu pengetahuan yang menyebabkan adanya sekelompok orang yang menemui hambatan untuk menciptakan kehidupan yang layak, melalui ilmu pengetahuan yang mereka miliki. Oleh karena itu, perlu untuk mendirikan lembaga

${ }^{10}$ Maksum, Madrasah, Sejarah dan Perkembangannya, hlm. 62-63.

${ }^{11}$ Pada era klasik hingga abad pertengahan Islam (abad ke-7 sampai abad ke-14 M), di mana peradaban Islam mencapai puncak kecemerlangannya, masjid tidak sekadar dijadikan sebagai tempat untuk menunaikan ibadat salat, tetapi masjid juga menjadi pusat pencerdasan masyarakat muslim. Masjidmasjid itu kemudian disebut dengan Jami'. Ada tiga Jami' yang sangat terkenal dengan aktivitas keilmuannya dalam dunia Islam yaitu 1) Jami' alMansur di Bagdad, 2) Jami' Umawi di Damaskus, dan 3) Jami' Amr Ibnul As di Mesir. Di dalam Jami' tersebut tidak hanya dipelajari baca tulis al-Quran, Tafsir, Hadis, Fikih, Ilmu Kalam, dll. Tetapi juga dipelajari ilmu pengetahuan Bahasa dan Kesusastraan, Ilmu Kedokteran, dan Matematika (Ilmu Hisab). Masjid jenis ini biasanya dilengkapi dengan asrama (khanqah) bagi para siswa dan para guru. Para pengajar tidak hanya guru-guru biasa tetapi juga para guru besar yang sekaligus menjadi imam masjid. Maqdisi menulis, "The professor, who usually also imam of the masjid. ...there were times, however, when professors took liberty of lodging in the mosques in which they taught". Lebih jauh tentang aktivitas ketiga Jami' tersebut baca George Makdisi, The Rise of Colleges; Institution of Learning in Islam and The West (Edinburgh: Edinburgh University Press, 1981), hlm. 9-24; Ahmad Syalaby, "Sedjarah Pendidikan Islam, terj. Muchtar Jahja, dan Sanusi Latief, (Jakarta: Bulan Bintang, 1973), hlm. 96-105. 
pendidikan yang dikelola secara profesional. ${ }^{12}$ Sebagai contoh, pengelola madrasah Nizamiyah sudah menerapkan sistem penggajian kepada pakar yang terlibat aktif dalam kegiatan keilmuan, walau pun hal ini masih kontroversial di kalangan para pakar dalam madrasah Niẓamiyah sendiri. ${ }^{13}$ Selain itu, madrasah juga didirikan sebagai sarana untuk mencetak para pekerja Sunni profesional yang akan berpartisipasi dalam menjalankan birokrasi pemerintahan, khususnya dalam bidang peradilan dan manajemen.

Sebagai lembaga ilmu pengetahuan, harus diakui bahwa madrasah didirikan tidak hanya untuk kepentingan jangka pendek seperti di atas, tetapi untuk merekonsiliasi wahyu dengan capaian ilmiah dan intelektual pada saat itu. Hal ini, bisa dimengerti karena pada dasarnya madrasah dibangun sebagai akibat dari kesadaran umat Islam akan pentingnya ilmu pengetahuan, sebagai kelanjutan dari adanya hubungan yang intensif antara dunia Islam dengan budaya intelektual yang berasal dari Yunani.

Menurut Gary Leiser, paling tidak terdapat tiga alasan utama pendirian dan pengembangan madrasah di dunia Sunni: 1) madrasah dibangun untuk mengokohkan paham Sunni dan membendung meluasnya paham Syi'ah. 2) madrasah didirikan untuk menyediakan kader-kader yang loyal terhadap pemerintah yang berkuasa, dan 3) keinginan penguasa untuk tetap bisa mengontrol dan mendapatkan dukungan para elit agama. ${ }^{14}$ Terkait dengan alasan pertama tersebut, Fazlur Rahman nampaknya sangat tidak sependapat, menurutnya madrasah sebagai kontra propaganda terhadap Syi'isme tampaknya secara mendasar tidaklah benar, karena madrasahmadrasah Sunni sudah ada sebelum propaganda Syi'ah, tetapi

${ }^{12}$ Bayard Dodge, Muslim Education in Medieval Time, (Washington: The Middle East Institute, 1962), hlm. 19-24. Mehdi Nakosteen, History of Islamic Origins, hlm. 49.

${ }^{13}$ Dodge, hlm. 20. Imam al-Ghazali (mengajar di madrasah Nizamiyah selama empat tahun, 1091-1095 M) misalnya sangat menentang pemberian upah bagi orang yang mengajarkan al-Quran atau ilmu agama, karena dipandang dapat mengurangi keikhlasan, sedangkan syarat utama menjadi guru adalah harus berjiwa muhliṣ. Ia mengatakan, siapa yang memberi ilmu untuk mendapatkan harta, maka ia sama dengan orang yang mengusap bagian bawah sandalnya ke mukanya sendiri, ia jadikan orang yang dilayani menjadi pelayan dan pelayan menjadi orang yang dilayani. Baca al-Gazāili, Ihy $\bar{a}^{`}$ Ulūm al-Dīn, Juz I, hlm. 5 .

${ }^{14}$ Gary Leiser, "Notes on Madrasah in Medieval Islamic Society”, The Muslim World, Vol. LXXVI, 1986, hlm. 18-19. 
adalah benar bahwa apa yang dilakukan Syi'ah selama kekuasaan politik mereka, yakni menggunakan lembaga-lembaga akademis mereka sebagai alat propaganda, selanjutnya menyebabkan penguasa-penguasa Sunni (Bani Saljuk dan Bani Ayyub) setelah runtuhnya kekuasaan Syi'ah, memberikan dukungan kepada lembaga-lembaga pendidikan Sunni. ${ }^{15}$ Madrasah itu berfungsi tidak hanya sebagai institusi transmisi ilmu, tetapi juga sebagai locus utama reproduksi ulama. Hingga akhir abad ke-13, madrasah menjadi wahana utama bagi kebangkitan doktrin Sunni. ${ }^{16}$

Dari penjelasan tersebut, dapat dipahami bahwa madrasah didirikan karena berbagai motif, kecenderungan dan kepentingan, baik agama, keilmuan, ekonomi maupun politik. Akan tetapi, berbagai faktor tersebut secara langsung maupun tidak, telah menyebabkan berkembangnya sistem pendidikan madrasah, yang merupakan tipe baru dari sistem pendidikan di dunia muslim.

Pada perkembangannya, keberadaan madrasah sebagai lembaga pendidikan tinggi (Islamic college), pada abad pertengahan tidak saja berpengaruh terhadap dunia Islam, tetapi juga memberikan kontribusi yang signifikan bagi perkembangan sistem pendidikan di dunia Barat. Bahkan oleh Elmer Harrison Wilds, seorang profesor pendidikan dari Michigan University menjelaskan bahwa, sistem pendidikan di dunia muslim (sistem madrasah) diakui menjadi salah satu fondasi pendidikan modern (the foundations of modern education), terutama dalam pengembangan pengetahuan ilmiah, dan sistem pengelolaan lembaga pendidikan. ${ }^{17}$ Walau pun kenyataan ini tidak banyak mendapat pengakuan dari para ahli sejarah di dunia Barat, yang disebabkan karena adanya sentimen keagamaan.

${ }^{15}$ Fazlur Raḥman, Islam (Islām), terj. Aḥsin Moḥamad (Bandung: Pustaka, 1994), hlm. 267.

${ }^{16}$ Azyumardi Azra, Jaringan Ulama Timur Tengah dan Kepulauan Nusantara Abad XVII dan XVIII; Akar Pembaruan Islam di Indonesia, (Jakarta: Kencana, 2004), hlm. 56.

${ }^{17}$ Wilds menjelaskan bahwa the system of education arranged at Basra, was a marvel of completeness. ...comprised fifty one treatises arranged under four heads: (1) thirteen treatises on logic, (2) seventeen treatises on natural sciences, (3) ten treatises on metaphysics, and (4) eleven treatises on theology. Elmer H. Wilds, The Foundations of Modern Education, (New York: Rinehart \& Company, Inc., 1957), hlm. 206-225; baca pula Nakosteen, History of Islamic Origins, hlm. 179-196. 


\section{Penyebaran Tradisi Islam di Jawa}

Sebelum berbicara lebih jauh tentang madrasah di Jawa, sangat perlu untuk dibahas terlebih dahulu tentang kedatangan dan penyebaran tradisi Islam di Jawa secara sekilas. Karena berawal dari kedatangan dan penyebaran tradisi Islam inilah kemudian lahir, tumbuh dan berkembangnya lembaga-lembaga pendidikan Islam seperti pengajian al-Qur'an, pengajian kitab, pondok pesantren dan madrasah di Pesisiran. Lembaga-lembaga pendidikan itu dibutuhkan keberadaannya, karena tuntutan umat untuk belajar agama Islam dalam berbagai aspeknya. Pemeluk Islam dari waktu ke waktu terus bertambah dan bertambah banyak, sehingga membutuhkan kehadiran lembaga-lembaga pendidikan agama yang bersifat masif untuk memperkuat keimanan dan keislamannya.

Proses masuk dan berkembangnya Islam di Jawa (Islamisasi Jawa), hendaknya dipahami sebagai proses yang dimulai dengan kedatangan Islam, kemudian disusul dengan penerimaan Islam, dan berakhir dengan pelembagaan Islam di Jawa. Kedatangan Islam adalah satu tahap di mana orang-orang yang beragama Islam yang berasal dari luar negeri datang ke Jawa. Sedangkan yang dimaksud dengan tahap penerimaan Islam adalah suatu tahap, di mana telah terdapat masyarakat pribumi yang menerima Islam sebagai keyakinan atau agamanya. Sedangkan tahap pelembagaan Islam adalah saat di mana ajaran Islam telah melembaga atau memasuki struktur masyarakat. ${ }^{18}$

Sebagaimana dimaklumi, bahwa tradisi yang hidup dan berkembang di Jawa sebelum datangnya Islam adalah tradisi HinduBudha yang berpusat di daerah pedalaman Jawa. Setelah zaman prasejarah serta kurun kepercayaan Animisme, Hinduisme tiba di Jawa. Menurut kebanyakan dugaan, Jawa dan pulau-pulau sekitarnya menganut agama Hindu dimulai pada abad I Masehi, dan kerajaan Jawa Hindu berlangsung dari abad VIII sampai abad XVI dan dibagi menjadi dua bagian: kerajaan Jawa Tengah dan Jawa Timur. Selain itu Budhisme datang ke Jawa pada abad VII. ${ }^{19}$

${ }^{18}$ Saleh Putuhena, Historiografi Haji Indonesia, (Yogyakarta: LKiS, 2007), hlm. 83.

${ }^{19}$ Zaini Muhtarom, Islam Jawa dalam Perspektif Santri dan Abangan, (Jakarta: Salemba Diniyah, 2002), hlm. 55. 
Seorang pengembara China, Cheng $\mathrm{Ho}^{20}$ dari Dinasti Ming (Ming Se), melakukan ekpedisi pada tahun 1405 hingga 1433, dilaporkan pernah singgah di Semarang, dan membangun beberapa masjid dengan ciri gaya atap tiga di beberapa tempat di antaranya di Semarang, Ancol, Tuban, Gresik dan Cirebon, yang merupakan prototipe masjid di Jawa. Cheng Ho mencatat bahwa pada masa itu (1405-1455), orang-orang China muslim bermazhab Hanafi telah berada di Jawa dan berperan dalam memfasilitasi penyebaran Islam di Jawa. ${ }^{21}$ Laporan Cheng Ho itu kemudian diperkuat oleh laporan dari Ma Huan, Fei Xin, dan Gong Zeng yang mencatat kehadiran pemukim China yang mencakup beberapa China muslim dalam jumlah cukup besar dari Zhang Zhou, Fujian dan Guang Dong di Jawa dan Palembang. Ma Huan, yang mengunjungi daerah pesisir utara Jawa pada tahun 1413.

Enam tahun sebelum wafatnya Maulanā Mālik Ibrāhīm, juga melaporkan keberadaan orang-orang China muslim di Jawa, dalam bukunya Ying-yai Sheng-lan, bahwa ada tiga macam penduduk di Jawa yaitu: 1) orang-orang muslim yang datang dari Barat, dan telah menjadi penetap, pakaian dan makanan mereka bersih dan pantas, 2) orang-orang China yang lari dari negerinya dan menetap di sini, pakaian dan makanannya juga baik-baik, banyak di antaranya yang beragama Islam dan taat melaksanakan amal ibadah agamanya, dan 3) penduduk asli yang hampir tidak berpakaian dan rambut tidak disisir dengan kaki telanjang, mereka sangat memuja roh. Dari laporan-laporan para pengembara China ini, Cheng Ho maupun Ma Huan, diketahui bahwa orang-orang China berperan besar dalam penyebaran Islam di Jawa terutama daerah pesisir.

\footnotetext{
${ }^{20}$ Cheng Ho (1371-1433) berasal dari Provinsi Yunan, dikenal sebagai Kasim San Bo atau pelayan. Karena pada usia 12 tahun ia sudah menjadi kasim atau pelayan atau disebut Thai Chien. Ayah Cheng Ho bernama Ma haji (1344-1382) yang juga seorang pelaut, dan ibunya bermarga Oen. Karena prestasinya ia diangkat sebagai kepala Kasim istana, dan pada awal abad XV, Kaisar Zhu mengutusnya untuk melakukan pelayaran ke samudra Hindia Barat, dan mengangkatnya sebagai laksamana. Dalam pelayaran inilah, Cheng Ho sempat singgah di Semarang pada tahun 1406. Baca: Kong Yuanzhi, Muslim Tionghoa Cheng Ho: Misteri Perjalanan Muhibah di Nusantara, (Jakarta: Pustaka Pepuler Obor, 2005), hlm. 71.

${ }^{21}$ Tan Ta Sen, Cheng Ho: Penyebar Islam dari China ke Nusantara, (Jakarta: Penerbit Buku Kompas, 2010), hlm. 254. Baca pula Kong Yuanzhi, Muslim Tionghoa Cheng Ho, hlm. 91-99.
} 
Sedangkan Tome Pires yang pernah berkunjung ke Nusantara antara tahun 1512 hingga 1515, juga mencatat bahwa para penduduk pribumi yang mendiami pesisir utara Jawa masih memuja roh dan menyembah berhala (beragama Hindu-Budha), sementara para pedagang Arab, Persia, dan Gujarat yang berdomisili di daerah itu mulai menjadi kaya dan jumlahnya bertambah banyak. Pires juga mencatat bahwa pedagang-pedagang muslim itu telah melakukan pernikahan dengan perempuan-perempuan pribumi yang telah diIslamkan. Mereka berdiam dalam suatu perkampungan yang eksklusif. Dari penjelasan Ma Huan dan Pires tersebut, dapat dipahami bahwa di pesisir utara Jawa sudah terdapat penduduk muslim kalangan pendatang, sedangkan penduduk pribumi masih banyak yang menganut agama Hindu-Budha.

Tradisi Islam masuk ke Jawa pada abad XIII lewat Sumatra yang sudah lebih dulu menerima pengaruh tradisi Islam. Dijelaskan oleh Degraaf dan Pigeaud, bahwa besar sekali kemungkinannya pada abad XIII di Jawa sudah ada orang Islam yang menetap. Sebab, jalan perdagangan laut, yang menyusuri pantai timur Sumatra melalui laut Jawa ke Indonsia Timur, sudah ditempuh sejak lama. Para pelaut itu, yang sebagiannya beragama Islam, dalam perjalanannya singgah dan menetap di pusat-pusat permukiman di pantai utara Jawa. Hal senada juga dikemukakan oleh Dennis Lombard, bahwa pada abad XIII telah terjadi perubahan mendasar atau "krisis" dalam sejarah Semenanjung Indocina dan Asia Tenggara. Di mana di Nusantara, Hinduisme dan Mahayanisme yang telah lama membekas pada seni dan mentalitas orang, digantikan oleh ideologi baru yaitu Islam. ${ }^{22}$ Di Jawa Tengah, pada abad XIII Islam tampaknya mulai diterima di pesisir daerah itu, ketika seorang pangeran dari Tuban, kota perdagangan yang mulai ramai dikunjungi pada waktu itu,memeluk Islam dan sebagai konsekuensinya Islam dinyatakan sebagai agama resmi negara.

Selanjutnya pada abad XIV, suatu gerakan dakwah yang lebih berhasil dilancarkan oleh Maulanā Mālik Ibrāhīm (w. 1419) yang mendarat di Gresik bersama beberapa orang kawannya, dan menetap di sana. Di Gresik dia memperoleh kesuksesan dalam misinya yaitu menyebarkan agama Islam dan berhasil memikat banyak

${ }^{22}$ Lebih rinci lihat: Dennys Lombard, Nusa Jawa: Silang Budaya Bagian 2 (Le Carrefour Javanais), terj. Winarsih Partaningrat Arifin, Rahayu S. Hidayat, dan Nini Hidayati Yusuf, (Jakarta: Gramedia, 2005), hlm. 29-36. 
pengikut. ${ }^{23}$ Pada saat itu, Jawa di bawah kekuasaan Majapahit yang beragama Hindu-Budha. Dalam sejarah penyebaran Islam di Jawa Maulanā Mālik Ibrāhīm dikenal sebagai penyiar Islam pertama di Jawa. Maulanā Mālik Ibrāhìm itulah mula-mula teta lering waliyullāh, nenek moyang pertama bagi para wali. Karena dari anak cucu beliau lahir para wali di Jawa. Beliau sendiri adalah ulama keturunan Rasulullah saw., dari cicit beliau Zainal 'Abidin bin Hasan bin 'Ali. ${ }^{24}$

Menurut Babad Tanah Jawi, ${ }^{25}$ penyebaran tradisi Islam di Jawa dilakukan oleh para Walisongo. Para pengarang babad Jawa bertahan bahwa Agama Islam telah didakwahkan di pulau Jawa oleh kesembilan mubalig yang dianggap sebagai orang saleh yang disebut wali. Nama-nama para wali dijunjung tinggi dan disesuaikan dengan tempat pemakaman atau kelahirannya, yaitu: 1) Sunan Gresik, bernama Maulanā Mālik Ibrāhìm atau Maulanā Magribi, wafat dan dimakamkan di Gresik pada tahun 1419 M. 2) Sunan Ampel atau Raden Rahmat yang mendirikan pesantren di Ampel dekat Surabaya. Ia wafat dan dimakamkan di dekat masjid Ampel pada tahun 1467 M. 3) Sunan Bonang atau Makhdum Ibrähïm adalah putra Sunan Ampel. Ia memimpin pengislaman Jawa bagian pantai timur laut. Beliau wafat pada tahun $1525 \mathrm{M}$ dan dimakamkan di Bonang. 4) Sunan Drajat atau Syarifudin, yang bernama asli: Qasim bin Muhammad Ali Rahmatullāh bin Ibrāhìm Assamarqand $\bar{y}$, seorang putra yang lain dari Sunan Ampel dan wafat pada tahun 1552. 5) Sunan Giri atau Raden Paku dianggap oleh orang Jawa sebagai pencipta lagu Jawa Pucung dan Asmarandana. Ia mendakwahkan Islam di sebelah timur pulau Jawa, ia wafat pada tahun 1530 M. 6) Sunan Kudus atau Ja'far Șadiq, ia adalah

\footnotetext{
${ }^{23}$ Thomas W Arnold, The Spread of Islam in The World, A History of Peaceful Preaching, (New Delhi: Goodword Books, 2001), hlm. 378.

${ }^{24}$ Widji Saksono, Mengislamkan Tanah Jawa, Telaah atas Metode Dakwah Walisongo, (Bandung: Mizan, 1995), hlm. 24. Baca pula: M.C. Ricklefs, Sejarah Indonesia Modern 1200-2004 (A History of Modern Indonesia since c 1200), terj. Satrio Wahono dkk., (Jakarta: Serambi, 2007), hlm. 32 .

${ }^{25}$ Babad Tanah Jawi dikenal sebagai kronik dan sastra sejarah Jawa. Karya ini diciptakan pada zaman kerajaan Mataram pada awal abad XVII. Para pujangga keraton Sultan Agung menciptakan Babad Tanah Jawi yang dimaksudkan untuk menggantikan kisah sejarah Jawa yang lama dan digunakan untuk menyesuaikan catatan zaman lampau dengan syarat-syarat zaman sekarang.
} 
putra sunan Ngudung yang berarti ia cucu Sunan Ampel, berpengaruh sekali dalam pengislaman di daerah sepanjang pantai utara Jawa Tengah. Ia pencipta lagu Maskumambang dan Mijil. Ia wafat pada tahun $1560 \mathrm{M}$ dan dimakamkan di Kudus. 7) Sunan Muria atau Raden Prawoto, ia adalah putra sunan Kalijaga, yang menggunakan gamelan untuk mengajak orang masuk Islam. Ia menggubah lagulagu Jawa Sinom dan Kinanthi. Ia dimakamkan di gunung Muria dekat Kudus. Tidak jelas tahun berapa ia wafat. 8) Sunan Gunung jati atau Syarif Hidayatullāh, yang terkenal sebagai Fatahillah, ia mengislamkan penduduk Jawa Barat. Ia wafat pada tahun $1570 \mathrm{M}$ dan dimakamkan di Cirebon, dan 9) Sunan Kalijaga atau Raden Syahid mengislamkan penduduk Jawa Tengah bagian selatan. Ia dianggap sebagai pengarang cerita-cerita wayang kulit. Ia wafat pada tahun $1585 \mathrm{M}$ dan dimakamkan di Kadilangu Demak. ${ }^{26}$

Islamisasi di Jawa memasuki tahap pelembagaan pada awal abad XVI, yang ditandai dengan berdirinya kerajaan Islam pertama di Jawa, Demak. Sebagai hasil dari Islamisasi yang dilakukan oleh para Walisongo. Para ahli sepakat bahwa Islamisasi di Jawa, yang dimotori oleh para Wali dilakukan dengan damai, yaitu dengan cara asimilasi dan akulturasi terhadap tradisi yang sudah ada sebelumnya. Dalam hal ini, Thomas W. Arnold menulis bahwa masuk dan menyebarnya doktrin Islam di Jawa, tidak dapat disangkal untuk masa yang lama, adalah semata-mata merupakan hasil usaha perorangan dari para saudagar atau pemimpin rombongan-rombongan kecil kaum pendatang, sebab di Jawa tidak ada kekuatan Islam yang terpusat untuk melancarkan pengaruhnya atau memaksakan perkembangannya dengan jalan perang. Arnold lebih jauh menegaskan bahwa, perkembangan Islam di Jawa bukanlah hasil dari suatu gerakan fanatik yang dikendalikan oleh orang-orang Arab, melainkan lebih merupakan suatu revolusi yang digerakkan oleh penduduk asli yang mendesak kekuasaan dari tangan orangorang Hindu-Budha tanpa mengobarkan perang.

Dari pendapat Arnold tersebut, dapat digaris bawahi bahwa masuk dan berkembangnya Islam di tanah Jawa lebih merupakan suatu gerakan kebudayaan (cultural movement), bukan merupakan gerakan atau misi politik (political movement), yang biasanya disertai dengan peperangan.

${ }^{26}$ Purwadi, dkk., Jejak para Wali dan Ziarah Spiritual, (Jakarta: Kompas, 2006), hlm. 10-25. 


\section{Murid Jawi dan Keberadaan Madrasah di Jawa}

Secara historis, keberadaan madrasah di Jawa tidak dapat dipisahkan dari hubungan ulama Timur Tengah khususnya Haramayn $^{27}$ dan al-Azhar ${ }^{28}$ Kairo dengan para murid Jawi-nya. Hubungan di antara negara Timur Tengah dengan Nusantara sejak kebangkitan Islam sampai paruh kedua abad XVII menempuh beberapa fase. Dalam fase pertama, sejak akhir abad VIII sampai akhir abad XII, hubungan-hubungan yang ada pada umumnya berkenaan dengan perdagangan. Pada fase berikutnya, sampai akhir abad XV, hubungan antara kedua kawasan ini mulai mengambil aspek-aspek yang lebih luas, yaitu mulai mengintensifkan penyebaran Islam di berbagai wilayah Nusantara. Pada tahap ini hubungan keagamaan dan kultural terjalin lebih erat. Fase ketiga, sejak abad XVI sampai paruh kedua abad XVII, hubungan yang terjalin lebih bersifat politik di samping keagamaan, terutama pada penguasa Haramayn. Dalam periode ini, muslim Nusantara semakin banyak ke tanah suci, yang pada gilirannya mendorong terciptanya jalinan keilmuan antara Timur Tengah dengan Nusantara melalui ulama Timur Tengah dan murid-murid Jawi. ${ }^{29}$

Kecenderungan kaum muslim Jawa untuk menjadikan Makkah sebagai kiblat sejati telah berlangsung selama periode Walisongo pada abad XV hingga abad XVI. Pada masa kewalian ini, tampaknya konsep kiblat tidak hanya terbatas pada penghormatan pada

${ }^{27}$ Haramayn bermakna dua tempat haram yaitu Makkah dan Madinah. Orang-orang Muslim Jawa menyebut Makkah, sebagaimana dikenal secara umum dalam bahasa Arab, dengan al-Mukarramah (kota suci), dan menyebut Madinah dengan al-Munawwarah (kota yang bersinar). Kota suci Makkah dan Madinah oleh umat muslim Jawa diyakini memiliki banyak keutamaan ( $f a-$ $d_{\bar{a}}^{-}$'il), hal inilah yang menyebabkan adanya pandangan bahwa ilmu yang diperoleh di Haramayn dipandang lebih tinggi nilainya dari pada ilmu yang diperoleh di pusat-pusat keilmuan lainnya.

${ }^{28}$ Al-Azhar atau Jami' al-Azhar adalah perguruan tinggi tertua dan ternama di dunia Islam, bahkan merupakan the greatest mosque university di dunia. Al-Azhar didirikan oleh Khalifah al-Mu'izz Dinasti Fatimiyah pada abad X (970 M) setelah panglima Jawhar al-Siqilli menaklukkan Mesir, dan membangun Kairo. Pada awalnya al-Azhar didirikan untuk misi penyebaran faham Syiah Ismailiah, namun pada perkembangannya (1171) berubah menjadi benteng faham Sunni. Lebih jauh baca John L. Esposito, The Oxford Encyclopaedia of The Modern Islamic World, vol. I, (Oxford: Oxford University Press, 1995), hlm. 168-171.

${ }^{29}$ Azra, Jaringan Ulama Timur ..., hlm. 49-50. 
kota suci, tetapi juga telah meluas pada penyebaran ilmu pengetahuan Islam standar, yang ditulis dalam bahasa Arab oleh para ulama Sunni. ${ }^{30}$

Keterjalinan keilmuan tersebut yang pada masa-masa berikutnya menumbuhkan kesadaran untuk membangun sebuah lembaga pendidikan keagamaan baik berupa pesantren maupun madrasah di Jawa khususnya dan Indonesia pada umumnya.

Sejak Syekh Yūsuf Makassar dan Abdurrauf Sinkel melanjutkan pendidikannya di Haramain pada abad XVII, jumlah penduduk Nusantara yang belajar di kedua kota suci itu, terutama Makkah, makin bertambah banyak. Para penuntut ilmu, selain sengaja berangkat ke Haramayn untuk belajar, mereka juga yang setelah melaksanakan ibadah haji, sambil menunggu transportasi untuk kembali ke tanah air, memanfaatkan waktu luangnya untuk belajar di masjid al-Haram atau di rumah seorang guru. Mereka yang bermaksud menuntut ilmu, setelah selesai melaksanakan ibadah haji, biasanya menetap di Makkah untuk beberapa tahun lamanya. mereka itu biasa disebut oleh penduduk setempat sebagai Jawah atau Jawi (orang Jawa) yang bentuk jamaknya adalah Jawiyin. ${ }^{31}$ Bagi orang Jawa sejak dulu, ibadah haji selain merupakan kewajiban syariat bagi yang mampu, naik haji juga sebagai wahana untuk mencari legitimasi ngelmu, karena Makkah adalah pusat dunia dan sumber ilmu. ${ }^{32}$

Dijelaskan oleh Steenbrink, bahwa antara tahun 1876-1886 M jumlah orang Jawa-Madura yang berangkat ke Makkah untuk menunaikan ibadah haji tercatat sebanyak 34.343 jiwa, dan dari jumlah itu yang kembali ke Jawa-Madura hanya 27.932 orang. Dengan demikian ada selisih 6.411 orang, mereka adalah haji yang meninggal dunia dan haji yang bermukim langsung di Makkah untuk menuntut ilmu di tanah suci. ${ }^{33}$ Oleh karena itu, setiap musim haji ada sejumlah jamaah haji yang menetap di Makkah, maka jumlah dengan sendirinya juga makin bertambah banyak. Ketika

${ }^{30}$ Abdurrahman Mas'ud, Dari Haramayn ke Nusantara; Jejak Intelektual Arsitek Pesantren, (Jakarta: Kencana, 2006), hlm. 90.

${ }^{31}$ Putuhena, Historiografi Haji ..., hlm. 343.

${ }^{32}$ Martin van Bruinessen, Kitab Kuning, Pesantren dan Tarekat, TradisiTradisi Islam di Indonesia, (Bandung: Mizan, 1995), hlm. 42-48.

${ }^{33}$ Untuk data lebih rinci per daerah dan per tahunnya baca Karel A. Steenbrink, Beberapa Aspek Tentang Islam di Indonesia Abad ke-19, (Jakarta: Bulan Bintang, 1984), hlm. 248-253. 
diadakan pencatatan Indonesia untuk pertama kalinya pada tahun 1912, jumlah mereka telah mencapai 5.500 orang. Akan tetapi, jumlah Indonesia itu sering berkurang secara drastis karena terjadi repatriasi secara besar-besaran ke Indonesia, terutama bila terjadi peristiwa tertentu, misalnya terjadinya perang dunia I (1914-1918), dan terjadinya peperangan antara Abd. Aziz Ibn Saud dengan Raja Husein sang penguasa Hijaz (1924-1925).

Pada perkembangannya, para penduduk Indonesia, yang karena ketekunannya dan telah menguasai ilmu pengetahuan agama yang cukup, mereka akan mendapat kepercayaan untuk mengajar atau sebagai guru. Snouck Hurgronje mencatat sejumlah guru dari muqimin Indonesia telah mengajar di Makkah pada pertengahan kedua abad XIX, ketika ia tinggal di Hijaz. ${ }^{34}$ Beberapa orang yang terkemuka di antaranya adalah:

1. Junaid dari Batavia. Dia telah menetap di Makkah selama 50 tahun secara terus menerus. Ia mengajar bahasa Arab pada murid-muridnya dari Batavia dan Jawa di rumahnya sendiri. Selain itu, ia juga mengajar berbagai ilmu agama di Masjidil Haram kepada murid-muridnya.

2. Muhammad Garut dari Priangan. Dia datang ke Makkah sebagai seorang guru untuk mendalami ilmu agama. Ia belajar dari guru-guru yang berasal dari Mesir dan Daghestan. Kemudian ia menetap di Makkah, lalu mengajarkan bahasa Arab dan Fikih meskipun perhatian utamanya adalah Tasawuf.

3. Muhammad Nawāwi atau yang lebih popular dengan sebutan Syekh Nawawi Banten atau Syekh Nawāwi al-Bantani. Ia berangkat ke Makkah dalam usia yang masih sangat muda. Ia pernah berguru pada Khatib Sambas dan Abdul Gani Bima, dua guru terkemuka dari generasi terdahulu, di samping itu juga belajar kepada Yūsuf Sumbulaweni, Nahrawi dari Mesir, dan Abdul Hamid Daghestani. Muhammad Nawāwi mengajarkan Tafsir al-Quran kepada murid-muridnya di rumahnya sendiri. Ia telah menulis beberapa kitab yang diterbitkan di Kairo dan Makkah, di antara karyanya adalah: al-Jurumiyah (1881), Lubāb al-Bayān (1884), Żari'ah al-Yaqīn (1886),

${ }^{34}$ C. Snouck Hurgronje, Mekka in The Latter Part of 19th Century, (Leiden: E.J. Brill, 1970), hlm. 262-290. 
Fatḥu al-Mujib (1881), Suluk al-Jadah (1883), dan Sullam alMunajāh (1884). ${ }^{35}$

4. Marzuki. Di kota suci Makkah ia belajar kepada Nawawi dan kepada guru-guru lainnya. Ia sudah menetap di Makkah selama sembilan tahun. Setiap hari setelah salat lima waktu ia mengajar sejumlah muridnya.

5. Ismail Banten atau yang sering disapa Tubagus karena masih keturunan Sultan Banten. Di Makkah ia belajar kepada guruguru Nawāwi, kecuali dalam bidang Aqidah dan Tasawuf ia belajar kepada Sayid al-Kutubi dari Mazhab Hanafi. Setelah beberapa tahun mukim di Makkah, Ismail kembali ke Banten untuk mengajar terutama dalam bidang Aqidah, Syari'ah dan Tasawuf. Akan tetapi, ia kemudian kembali lagi ke Makkah untuk menetap. Ia melanjutkan studinya di Masjid al-Ḥarām, sambil memberikan pelajaran bagi sejumlah muridnya setiap hari di rumahnya.

6. Abdul Karim Banten. Ia berangkat ke Makkah untuk belajar. Ia diminta oleh Ahmad Khatib Sambas untuk tinggal bersamanya dan melayani di rumahnya. Setelah melakukan perjalanan ke Singapura dan Banten, ia kembali lagi ke Makkah dan tinggal selama 11 tahun. Ia sangat menguasai Ilmu Tarekat. Setiap hari ia bersama muridnya melaksanakan zikir dan wirid. Ia sangat terkenal di kalangan jamaah haji dan masyarakat Asia Tenggara, sebagaimana pimpinan tarekat yang lain.

7. Abdul Syukur dari Surabaya. Ia berangkat ke Makkah dalam usia yang masih muda sambil mengharapkan untuk tinggal bersama seorang guru sebagai pelayan dan muridnya. Ia diterima sebagai pelajar dan pelayan oleh Sayid Muhammad Syatta. Ia juga belajar pada guru-guru yang pernah mengajar Nawawi. Ia mengajarkan Qawa'id, Manthiq, Adab, Fikih dan Tauhid. Ia juga sangat menggemari Tasawuf sehingga para muridnya dibimbing untuk dapat membaca dan memahami karya al-Ghazali dan Ibn 'Ața'illah.

${ }^{35}$ Untuk mengetahui sosok kehidupan intelektual Syekh Nawawi alBantani lebih jauh, baca Karel Steenbrink, Beberapa Aspek Tentang Islam di Indonesia Abad ke-19, (Jakarta: Bulan Bintang, 1984), hlm. 117-127. Baca pula Abdurrahman Mas'ud, Dari Haramayn ke Nusantara ..., hlm. 109-128, Abdurrahmman Mas'ud memberi gelar Nawawi al-Bantani sebagai Guru Besar pesantren di Jawa. 
8. Abdul Hamid dari Kudus. Dia dilahirkan di Makkah dari seorang ibu keturunan Arab. Gurunya adalah ulama terkemuka Sayid Aḥmad Dahlan dan Sayid Bakri. Ia adalah salah seorang ulama Indonesia yang mendapat kesempatan untuk mengajar di Masjid al-Ḥarām.

Di antara tokoh-tokoh tersebut, Muhammad Nawāwi atau yang lebih terkenal dengan sebutan Imam Nawāwi al-Bantani yang paling berpengaruh di kalangan santri dan kiai di Pesisiran Jawa. Kitab-kitab karangan Imam Nawāwi banyak dijadikan pegangan wajib dan rujukan di pesantren-pesantren di Jawa. Sedemikian rupa pengaruh pemikiran Nawāwi, sebagai guru intelektual tradisi pesantren, sehingga dia menduduki tempat yang sangat spesial dalam tradisi intelektual para santri di Jawa. ${ }^{36}$ Secara genealogis intelektual, kiai-kiai besar pesantren di Jawa pernah berguru secara langsung dengan Imam Nawāwi ketika di Makkah. ${ }^{37}$ Dengan demikian bisa dikatakan bahwa Imam Nawāwi adalah guru besar pesantren.

Dalam perkembangannya, pada dekade kedua abad XX terdapat sedikitnya 90 orang guru agama, di antaranya tiga orang perempuan yang mengajar berbagai macam ilmu pengetahuan agama. Sebagian besar mereka mengajar di rumah dan beberapa orang saja yang mengajar di Masjid al-Ḥarām. Dari para ulama tersebut dan para muridnya telah memperkenalkan sistem pendidikan keagamaan dan pemikiran Islam di Nusantara.

Selain aktivitas keilmuan di Masjid al-Ḥarām, aktivitas keilmuan di madrasah juga dapat ditemukan di Haramayn. Akan tetapi disebabkan karena kebanyakan ulama Haramayn lebih senang mengafiliasikan diri dengan Masjid al-Ḥarām dan Masjid al-Nabawiy, oleh karenanya aktivitas keilmuan di madrasah-madrasah $\mathrm{Ha}$ ramayn cenderung diabaikan. Demikian pula para pelajar Indonesia di Haramayn lebih banyak melakukan aktivitas keilmuan di Masjid al-Ḥarām ketimbang di madrasah-madrasah yang sebetulnya sudah ada di kota Makkah sekitar masjid al-Ḥarām.

Baru pada $1927 \mathrm{M} / 1345 \mathrm{H}$, tahun-tahun pertama pemerintahan Ibn Saud, terjadi perkembangan dalam penyelenggaraan pengajaran $109-156$

${ }^{36}$ Baca Abdurraḥman Mas’ud, Dari Haramayn ke Nusantara ..., hlm.

${ }^{37}$ Baca Zamakhsyari Dhofier, Tradisi Pesantren: Studi Tentang Pandangan Hidup Kiai, (Jakarta: LP3ES, 1982), hlm. 86. 
agama Islam di kalangan Indonesia di Makkah. Perkembangan itu ditandai dengan didirikannya sebuah madrasah tempat mengajar bagi guru-guru Indonesia serta dimasukkannya pengetahuan umum atau pelajaran sekuler sebagai bagian dari pelajaran yang diajarkan kepada para penuntut ilmu. Sebagaimana telah dijelaskan bahwa pada waktu itu para menuntut ilmu di rumah-rumah dan atau di masjid al-Ḥarām dan tidak diajarkan pengetahuan umum.

Sesungguhnya, kebangkitan madrasah di tempat-tempat lain di Timur Tengah dalam waktu tak terlalu lama segera mempengaruhi Haramayn. Menurut sejarawan Taqiy al-Din al-Fasi al-Makki alMalki (775-832 H/1373-1428 M), sebagaimana dijelaskan oleh Azyumardi Azra (2004 M), madrasah pertama di Makkah adalah Madrasah al-Urșufiyah yang didirikan pada 571/1175 oleh 'Afif 'Abdullāh Muhammad al-Ursufi (w. 595/1196) di dekat pintu Umrah, bagian selatan Masjid al-Ḥarām. Sejak pembangunan Madrasah al-Urșufiyah hingga awal abad XVII terdapat setidaknya 19 madrasah di Makkah. ${ }^{38}$

Ciri terpenting madrasah-madrasah di Makkah adalah hampir seluruh madrasah itu dibangun penguasa-penguasa atau dermawan nonHijaz. Yang terbanyak mendirikan madrasah di Makkah adalah penguasa Utsmani; mereka membangun 5 madrasah, yaitu 4 dibangun oleh Sultan Sulaiman al-Qanuni dan 1 madrasah dibangun oleh Sultan Murad. Selanjutnya, khalifah dan pejabat tinggi Abbasiyah membangun 4 madrasah. Penguasa-penguasa Mesir, termasuk Mamluk, dan penguasa Yaman, masing-masing mendirikan 3 madrasah. Kemudian, penguasa muslim India membangun 2 madrasah.

Selain di Makkah, sebagian jamaah haji juga menuntut ilmu atau melanjutkan studinya ke Universitas al-Azhār di Kairo Mesir. Di antara mereka, ada yang langsung berangkat ke Mesir seusai melaksanakan ibadah haji, sementara sebagian yang lain baru berangkat ke Mesir setelah beberapa lama belajar di Makkah. Tradisi belajar ke Universitas al-Azhār telah dimulai sejak akhir abad XIX, ketika Syekh Ismāil Abdul Muṭalib (44 tahun), seorang guru dari Padang tiba di Kairo pada 1894/1895. Pada 1912, sebanyak 37 pelajar menyusul ke Kairo untuk belajar. Sebagian besar pernah tinggal di Makkah paling kurang 1 tahun dan paling lama 8 tahun dengan usia termuda 15 tahun dan tertua 44 tahun.

${ }^{38}$ Azra, Jaringan Ulama Timur ..., hlm. 56-57. 
Perantau penuntut ilmu di Mesir berasal dari Sambas (11 orang), Sumatera Utara (6 orang), Pandeglang (5 orang), Palembang (4 orang), Padang dan Martapura (masing-masing 2 orang), sedangkan dari Batavia, Banten, Serang, Kendal, Pekalongan, Lampung dan Bengkulu masing-masing 1 orang.

Pada awal abad XX, pelajar Indonesia yang belajar Universitas al-Azhār makin bertambah banyak, dan di antara mereka yang telah menyelesaikan studinya di perguruan tinggi ini kemudian kembali ke Indonesia lalu membuka pesantren dan madrasah dengan memberikan pelajaran agama dan adakalanya juga pelajaran umum.

Sangat jelas, bahwa keberadaan madrasah di Jawa sebagai konsekuensi logis dari adanya jalinan intelektual atau jaringan ulama Timur Tengah dan kepulauan Nusantara yang dimulai sejak abad XVII, ${ }^{39}$ atau dapat pula dikatakan bahwa pertumbuhan dan perkembangan madrasah di Indonesia, khususnya di Jawa pesisiran dipengaruhi secara kuat oleh tradisi madrasah di Timur Tengah, khususnya Haramayn dan Mesir. Simpulan ini membantah tesis Steenbrink yang mengatakan bahwa keberadaan madrasah di Indonesia disebabkan karena pengaruh tradisi pendidikan model Barat terutama Belanda. ${ }^{40}$ Pendapat ini juga diikuti oleh Makșum yang menjelaskan bahwa sebagian madrasah-madrasah di Jawa lebih dekat dengan sistem persekolahan ala Belanda. ${ }^{41}$

Tesis pertama bahwa keberadaan madrasah di Indonesia, khususnya di Jawa lebih banyak dipengaruhi tradisi pendidikan Islam di Timur Tengah, khususnya Haramayn dan Kairo itu bisa dibenarkan. Hal ini disebabkan sifat para ulama yang nonkooperatif

${ }^{39}$ Azyumardi Azra dalam penelitiannya menegaskan bahwa akar pembaruan Islam di Indonesia secara menyeluruh dalam berbagai aspeknya dipengaruhi secara kuat oleh jalinan intelektual ulama Timur Tengah dan para muridmuridnya di kepulauan Nusantara. Lebih jauh tentang hal ini baca Azra, Jaringan Ulama Timur Tengah ....

${ }^{40}$ Steenbrink menjelaskan: "pada dasarnya sekolah yang dikelola (madrasah) kedua organisasi tersebut (maksudnya al-Irsyad dan Jami' at Khair) tidak berbeda dengan sistem pendidikan gubernemen, walaupun keduanya memberikan kesempatan yang lebih banyak kepada pendidikan agama. Dengan cara ini, kelompok masyarakat Arab juga memberikan sumbangan kepada penerimaan pembaharuan sistem Barat". Lebih lanjut baca Karel Steenbrink, Pesantren, Madrasah dan Sekolah; Pendidikan Islam dalam Kurun Modern, (Jakarta: LP3ES, 1994), hlm. 58-72.

${ }^{41}$ Makṣum, Madrasah, Sejarah dan Perkembangannya, hlm. 106. 
terhadap pemerintah Hindia-Belanda yang berarti sangat menolak segala bentuk tradisi atau budaya pendidikan Belanda.

Selain itu alasan yang lebih prinsip adalah, adanya pengaruh para pembaharu Timur Tengah terhadap gerakan umat Islam di Indonesia adalah sangat dimungkinkan, hal ini disebabkan karena terbukanya kesempatan untuk memperdalam Islam di pusat-pusat pendidikan Islam di negara-negara Arab. Melalui para murid Jawi dan para haji inilah ide-ide pembaharuan dalam dunia pendidikan dibawa dan diterapkan di Indonesia. Keberadaan madrasah di Jawaa tidak dapat dipisahkan dari peran para haji yang telah menjadi kiai atau ulama besar Nusantara sepulangnya dari Makkah dan Madinah, serta Kairo sesudah menunaikan ibadah haji, mereka biasanya bermukim di sana bertahun-tahun lamanya untuk menuntut ilmu agama dan bahasa Arab.

\section{E. Tempat Belajar Agama sebelum Madrasah di Pesisiran}

Praktik pendidikan Islam di Jawa sebetulnya sudah dimulai sejak zaman para Walisongo bersamaan dengan zaman kekuasaan kerajaan Demak, sebagai buktinya adalah pada tahun 1451 Raden Rahmat atau yang terkenal dengan sebutan Sunan Ampel mendirikan pesantren Ampel Denta atau Ampel Gading di Surabaya. ${ }^{42}$ Kemudian pada tahun 1475, Raden Ḥasan atau yang kemudian terkenal dengan sebutan Raden Fatah, atas ijin dan restu dari Sunan Ampel, juga mendirikan pesantren di Tlatah atau Alas Glagah Arum atau Glagah Wangi, suatu wilayah Perdikan yang masih berupa hutan yang terletak di antara Jepara dan Semarang. Kemudian untuk melengkapi sarana ibadah dan pendidikan, maka pada tahun 1477 di Tlatah Glagah Wangi ini didirikan sebuah masjid yang saat ini terkenal dengan Masjid Agung Demak.

Pada perkembangan selanjutnya, praktik pendidikan dan pengajaran Islam di Jawa mencapai puncak keemasannya pada zaman kekuasaan Kerajaan Islam Mataram (1575-1757), terutama pada masa pemerintahan Sultan Agung. Pada masa ini pendidikan Islam telah terstruktur secara rapi dan teratur, yang dapat diskemakan sebagai berikut:

${ }^{42}$ Muhammad Khafid Kasri, Pujo Semedi. Sejarah Demak: Matahari Terbit di Glagahwangi, (Demak: Kantor Pariwisata dan Kebudayaan Kabupaten Demak, 2008), hlm. 23. 


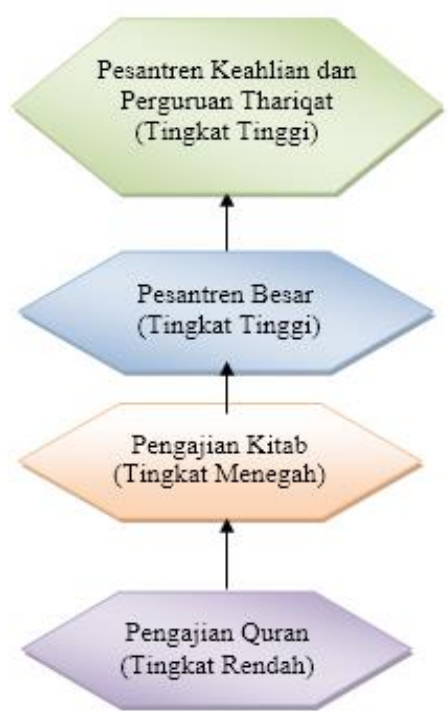

Gambar 1

Susunan Pendidikan dan Pengajaran Islam di Jawa pada masa Sultan Agung Mataram

Keberadaan madrasah di Jawa Pesisiran tentu tidak dapat dipisahkan dari keberadaan lembaga pendidikan Islam tradisional Jawa sebelum kemunculan madrasah yaitu pengajian al-Quran, pengajian kitab kuning, dan pondok pesantren. ${ }^{43}$ Agar lebih jelas, di bawah ini akan dipaparkan secara singkat lembaga-lembaga pendidikan Islam tradisional tersebut, seperti pada gambar 1 tersebut.

Pertama, bentuk lembaga pendidikan Islam yang pertama dan paling sederhana di Jawa adalah pengajian al-Quran. Secara umum, pengajian al-Quran dimulai dengan menghafal abjad Arab, dan menghafalkan teks-teks yang terdapat dalam al-Quran, terutama surat al-Fätihah dan kemudian surat-surat pendek yang ada dalam Juz'Amma yang juga disebut turutan. ${ }^{44}$ Selain pelajaran membaca

${ }^{43}$ Zamkhsyari Dhofier, Tradisi Pesantren; Studi Tentang Pandangan Hidup Kiai, (Jakarta: LP3ES, 1982), hlm. 21. Baca pula Steenbrink, Pesantren, hlm. 10-25.

${ }^{44}$ Disebut turutan karena cara mengajarkan kitab itu, adalah semata-mata menurut kata guru saja. "a" kata guru, maka "a" kata murid, "ba" kata guru, "ba" kata murid, "ta" kata guru, "ta" kata murid, dan seterusnya. Atau boleh jadi kitab itu disusun berdasarkan urut-urutan, mulai dari bagian yang paling mudah dan sederhana hingga yang paling rumit dan sulit, dari alif, $b a^{\prime}, t a{ }^{\prime}$ 
dan menghafal, di pengajian itu diajarkan pula peraturan dan tata cara salat, wudu dan bacaan-bacaannya yang disebut fasalātan. Hal yang demikian disebabkan karena bagi seorang Jawa, untuk dapat mengucapkan dua kalimat syahadat, mengerjakan sembahyang lima waktu, dan membaca al-Quran, diperlukan latihan dan pendidikan elementer yang secara tradisional diberikan dalam pengajianpengajian yang diselenggarakan di rumah guru-guru ngaji, di langgar, atau di masjid. ${ }^{45}$ Pengajian ini biasanya dilaksanakan setiap malam selepas salat Magrib bertempat di masjid, surau dan rumah kiai atau guru ngaji yang diikuti oleh anak-anak yang berumur antara 6 sampai 10 atau 11 tahun. Pengajian diberikan secara individual, dengan cara murid yunior belajar kepada murid senior dan murid senior kepada guru ngajinya.

Pengajian al-Quran ini diberikan secara individual kepada para murid. Biasanya mereka berkumpul di salah satu surau atau di serambi rumah sang guru. Mereka membaca dan melagukan ayatayat suci di hadapan guru satu persatu di bawah bimbingannya selama $1 / 4$ atau $1 / 2$ jam. Ketika salah seorang murid menghadap guru, murid lain dengan suara keras mengulang kajian kemarin atau lanjutan pelajaran yang telah diperbaiki gurunya. Jadi di dalam surau atau rumah semacam itu, orang dapat mendengar bermacammacam suara yang bercampur aduk menjadi satu. Tetapi karena semenjak kanak-kanak terbiasa hanya mendengar suara mereka sendiri, para murid tersebut tidak terganggu suara murid yang lain.

Kedua, adalah pengajian kitab. Dalam struktur pendidikan Islam tradisional di Jawa, pengajian kitab merupakan lanjutan dari pengajian membaca al-Quran. Setelah anak-anak tamat dari pengajian al-Quran, bagi anak-anak dari keluarga tertentu, biasanya hidup berkecukupan dan mempunyai tali hubungan kekeluargaan dengan kiai atau guru ngaji, biasanya mereka melanjutkan pelajaran untuk membaca dan menerjemahkan buku-buku Islam klasik yang elementer yang ditulis dalam bahasa Arab, yang disebut kitab kuning. Pengajian kitab ini biasanya dilakukan masjid, surau atau di rumah kiai atau guru ngaji. Pada pengajian kitab ini, para murid mempelajari bahasa Arab yang tersusun dalam uraian pendek yang

hingga 'Amma yatasāa alūn. Untuk menuntun murid-murid agar bisa membaca kitab suci al-Quran dengan baik dan benar.

${ }^{45}$ Zamakhsyari Dhofier, The Pesantren Tradition; The Role of The Kiai in The Maintenance of Traditional Islam in Java, (Arizona: Program for Southeast Asian Studies, 1999), hlm. 3. 
berbetuk sajak. Para murid diharuskan membaca dan menghafal teks Arab tersebut tanpa salah kemudian isinya dijelaskan oleh guru.

Pengajian kitab, bisa dikatakan sebagai cikal bakal pondok pesantren. Karena dari pengajian kitab yang hanya diikuti oleh beberapa murid dari sebuah desa atau kampung saja pada awalnya, yang kemudian berkembang diikuti oleh banyak murid dari berbagai daerah, dari sinilah kemudian terbentuk sebuah pondok pesantren di Jawa. Pada saat ini, pengajian kitab lebih banyak dilakukan di setiap bulan puasa Ramadan baik di masjid, surau, dan di rumah-rumah kiai atau guru ngaji. Akan tetapi, di pondok pesantren pengajian kitab salaf ini menjadi acara rutin setiap hari.

Ketiga adalah Pondok Pesantren. Keberadaan pondok pesantren ini tidak bisa dipisahkan dari peran dan pengaruh Walisongo dalam menyebarkan Islam pada abad XV-XVI di Jawa. Maulanā Mālik Ibrāhìm (w. 1419 M di Gresik), spiritual father Walisongo, dalam masyarakat santri Jawa dipandang sebagai gurunya guru tradisi pesantren di tanah Jawa. Akan tetapi, pondok pesantren sebagai lembaga pendidikan dalam pengertian modern baru dapat ditemukan setelah abad XVIII dan XIX.

Di Jawa anak-anak yang telah menyelesaikan belajar beberapa kitab pada guru ngaji atau kiainya di kampung, mereka kemudian melanjutkan belajarnya ke pondok pesantren atau biasa disebut pondok saja, mereka kemudian mendapat panggilan santri. Santri pondok pesantren pada umumnya dikelompokkan menjadi dua bagian, yaitu: Santri Muqim yaitu murid-murid yang berasal dari daerah-daerah yang jauh dan menetap dalam pesantren, dan Santri Kalong yaitu murid-murid yang berasal dari desa-desa sekeliling pesantren yang biasanya tidak menetap di pesantren untuk mengikuti pelajarannya di pondok pesantren, mereka bolak-balik dari rumahnya.

Pondok pesantren sebagai pendidikan Islam tradisional tingkat lanjut bertujuan untuk meninggikan moral, melatih dan mempertinggi semangat, menghargai nilai-nilai spiritual dan moral, serta menyiapkan para murid untuk hidup sederhana dan bersih hati, selain itu juga untuk memperkaya ilmu pengetahuan murid dengan penjelasan-penjelasan yang bersumber pada kitab-kitab klasik. Menurut Bruinessen bahwa alasan pokok munculnya pesantren di Indonesia adalah untuk mentransmisikan Islam tradisional sebagaimana terdapat dalam kitab-kitab klasik yang ditulis berabad-abad 
yang lalu. ${ }^{46}$ Keseluruhan kitab-kitab klasik yang diajarkan di pesantren dapat digolongkan kedalam 8 kelompok: 1) Nahwu dan Saraf, 2) Fiqh, 3)Usūul Fiqh, 4) Hadis, 5) Tafsìr, 6) Tauhìd, 7) Tasawwuf dan Akhlāq, dan 8) Tarikh dan Balāgah.

Dewasa ini pondok pesantren di Jawa, tidak hanya memainkan peran tradisionalnya saja, yaitu transmisi dan transformasi ilmuilmu keislaman, pemeliharaan tradisi muslim dan reproduksi intelektual ulama, namun lebih luas dari itu, pondok pesantren telah menjadi wahana pembangunan yang berpusat pada masyarakat (community centered development) dan sekaligus sebagai pusat pengembangan pembangunan yang berorientasi nilai (value centered development). Pondok pesantren telah memerankan multifungsi yaitu sebagai lembaga pendidikan keagamaan Islam, sebagai lembaga pengembangan intelektual, sosial ekonomi dan ilmu pengetahuan dan teknologi, sebagai lembaga wajib belajar pendidikan dasar, sebagai lembaga pendidikan kesetaraan, sebagai lembaga pendidikan tinggi, sebagai lembaga pengembangan olah raga, seni dan budaya, serta sebagai lembaga pertahanan moral juga wawasan kebangsaan.

\section{F. Madrasah Masa Awal di Pesisiran Jawa}

Tumbuh dan berkembangnya madrasah di Indonesia pada umumnya dan di Jawa khususnya pada permulaan abad XX, tidak dapat dipisahkan dengan tumbuh dan berkembangnya ide-ide pembaruan pemikiran di kalangan umat Islam. Adapun beberapa faktor pendorong timbulnya ide-ide pembaruan tersebut adalah: 1) pendidikan Islam tradisional dianggap kurang sistematis dan kurang memberikan kemampuan pragmatis yang memadai, 2) laju perkembangan sekolah-sekolah Belanda di kalangan masyarakat cenderung meluas dan membawakan watak sekularisme sehingga harus diimbangi dengan sistem pendidikan Islam yang memiliki model dan organisasi yang lebih teratur dan terencana.

Selain itu, hal yang lebih fundamental yang mendorong tumbuh dan berkembangnya madrasah di Jawa yaitu, bahwa pada penghujung abad XIX dan awal abad XX telah banyak alumnus Timur Tengah khususnya Kairo dan Haramayn kembali ke Jawa. Mereka yang kembali itu sesampai di daerah masing-masing

\footnotetext{
${ }^{46}$ Martin van Bruinessen, "Pesantren dan Tradisi Kitab Kuning Pemelihara dan Kesinambungan Tradisi Pesantren”, dalam Ulumul Qura'n, Vol.III, No.4 Tahun 1992, (Jakarta: LSAF-ICMI, 1992), hlm. 75.
} 
biasanya memiliki posisi-posisi penting dalam bidang pendidikan agama. Atas dasar upaya-upaya mereka maka timbul perubahanperubahan dalam sistem dan isi pendidikan Islam. ${ }^{47}$ Dalam kaitan ini, penulis tidak sependapat dengan Steenbrink dan Haidar Putra Daulay, yang mana mereka menyimpulkan bahwa keberadaan madrasah adalah karena ingin mencontoh sistem pendidikan Belanda, yang telah lebih maju dan modern.

Pertumbuhan madrasah merupakan respon umat Islam yang lebih progresif, dan tidak semata-mata defensif terhadap politik Hindia-Belanda. Perlu digaris bawahi, bahwa madrasah di Jawa Pesisiran, juga di tempat lain di Nusantara, lahir dan tumbuh di tengah suasana kolonialisme Belanda, yang memang tidak memberikan kebebasan bagi umat Islam untuk maju dan keluar dari keterbelakangannya. Di tengah-tengah situasi dan kondisi yang sangat sulit dan memprihatinkan itulah, maka madrasah tumbuh dan bertahan bahkan mampu berperan sebagai lembaga perjuangan, sekaligus lembaga pendidikan asli anak-anak pribumi, dan berkembang hingga saat ini. Secara kronologis beberapa madrasah yang tumbuh pada awal abad XX di Jawa Pesisiran:

Pada tahun 1901 (1318 H) di Kudus didirikan Madrasah Qudsiyah oleh KH. Raden Asnawi, ${ }^{48}$ sekembalinya beliau dari menuntut ilmu di Makkah. Madrasah Qudsiyah pada awalnya merupakan bentuk madrasah yang hanya mengajarkan kitab-kitab salaf. ${ }^{49}$ Madrasah ini mempunyai dua tingkatan yaitu Ibtidaiyah dan Tsanawiyah. Pada awal berdirinya Madarasah Qudsiyyah memfokuskan pada ilmu agama Islam saja, namun pada perkembangannya, yaitu sejak dikeluarkannya SKB 3 Mentri tahun 1975 tentang pembinaan dan peningkatan mutu madrasah di Indonesia, madrasah

\footnotetext{
${ }^{47}$ Haidar Putra Daulay, Historisitas dan Eksistensi Pesantren Sekolah dan Madrasah, (Yogyakarta: Tiara Wacana, 2001), hlm. 63.

${ }^{48}$ KH. R. Asnawi dilahirkan di dusun Damaran Kudus pada tahun 1864 dan meninggal dunia pada tahun 1959, Asnawi menunaikan ibadah haji pada tahun 1889 dan 1894, yang ketika itu beliau berumur 39 tahun. Beliau tinggal dan menuntut ilmu di Makkah selama 22 tahun. Guru-guru utamanya di tanah suci adalah KH. Saleh Darat Semarang, KH. Mahfuz at-Tirmizi, dan Sayyid Umar Shatta. Lebih jauh baca Abdurrạ̣man Mas'ud, Dari Haramayn ..., hlm. 206-227.

${ }^{49}$ Sejarah Singkat Qudsiyyah, http://www.qudsiyyah.com/index.php/ qudsiyyah/profil/2. diakses tanggal 29 Juni 2010.
} 
ini memasukkan mata pelajaran umum. ${ }^{50}$ Walaupun demikian, pada saat ini kurikulum Madrasah Qudsiyyah memuat pelajaran agama dan umum secara seimbang. Pada tahun 1957 jumlah murid tercatat 438 orang dan gurunya 12 orang. Madrasah Qudsiyah masih tetap eksis hingga saat ini, walaupun pernah ditutup pada masa pendudukan Jepang. Madrasah Qudsiyah merupakan madrasah pertama atau tertua di pesisiran Jawa.

Pada tahun 1912 di Pati, berdiri Madrasah Matāli'ul Falah yang didirikan oleh dua kiai bersaudara, Kiai Abdus Salam dan Kiai Nawāwi, keduanya memiliki hubungan genealogis dengan Kiai Mutammakkin. Madrasah ini oleh masyarakat setempat menyebutnya dengan sekolah Arab, sebuah sebutan umum untuk menunjuk lembaga pendidikan Islam. Pada mulanya madrasah ini hanya berupa Madrasah Diniyah tiga tahun yang seluruh materi pelajarannya hanya mencakup ilmu-ilmu agama saja. Introduksi mata pelajaran umum, seperti berhitung, ilmu bumi dan sebagainya mulai dilakukan pada tahun $1916 .{ }^{51}$

Di Kudus, pada tahun 1915, tepatnya pada tanggal 7 Juli 1915 didirikan Madrasah Muawwanatul Muslimin Kenepan (M3K) oleh Serikat Islam. Madrasah ini adalah setingkat Ibtidaiyah (dasar), dengan lama belajar 8 tahun terdiri dari kelas 0 , kelas $1 \mathrm{~A}$, kelas 1 $\mathrm{B}$, kemudian kelas II sampai VI, dan mata pelajarannya terdiri pelajaran agama dan pengetahuan umum. Pada tanggal 21 Nopember 1928 K.H. A. Khaliq mendirikan Madrasah Tasywiqut Tullab Balai Tengahan School. Madrasah ini terdiri dari dua tingkatan yaitu Ibtidaiyah dan Tsanawiyah. Di madrasah ini diajarkan hanya ilmuilmu agama dan bahasa Arab saja, dan sejak tahun 1935 dimasukkan pengetahuan umum. Pada tahun 1957 jumlah muridnya tercatat sebanyak 438 orang dengan 12 orang guru.

Sedangkan di Demak, madrasah pertama adalah Madrasah Futuhiyah yang didirikan oleh KH. Muṣlih pada tahun 1936, yang berada di lingkungan Pondok Pesantren Futuhiyah, di desa Suburan Kec. Mranggen. Madrasah ini merupakan cikal bakal madrasah di Kab. Demak. Pertumbuhan madrasah di Pesisiran Jawa, pada umumnya lebih banyak dipelopori oleh para kiai, atau pun para

\footnotetext{
${ }^{50}$ Mahmud Yunus, Sejarah Pendidikan Islam di Indonesia, (Jakarta: Mutiara Sumber Widya, 1961), hlm. 253.

${ }^{51}$ Arif Subhan, Lembaga Pendidikan Islam Indonesia Abad ke-20: Pergumulan antara Modernisasi dan Identitas, (Jakarta: Kencana, 2012), hlm. 194.
} 
tokoh yang menamatkan pendidikan di masjid al-Ḥarām Makkah. ${ }^{52}$ Perkembangan madrasah di Jawa Pesisiran, pada masa-masa berikutnya lebih banyak dibidani oleh organisasi-organisasi keagamaan seperti NU, dan Muhammadiyah. Sehingga menjadikan madrasah berkembang secara masif di seluruh pelosok Jawa, terutama di Tlatah pesisir utara Jawa.

\section{G. Penutup}

Dari tulisan tersebut, dapat ditarik kesimpulan bahwa tradisi madrasah bukan merupakan tradisi yang genuin Indonesia ataupun Pesisiran Jawa, akan tetapi merupakan tradisi yang berasal dari peradaban Islam di Timur Tengah, Baghdad, Makkah dan Madinah juga Kairo, yang telah berkembang jauh sebelum masuk dan berkembangnya Islam di Nusantara ataupun Jawa. Tradisi madrasah, yang merupakan imported tradition, tumbuh dan berkembang di Pesisiran Jawa, karena keberadaannya berperan penting dalam mendidikkan ilmu-ilmu agama Islam (tafaqqahu fi al-din) dan juga memberikan ilmu pengetahuan modern kepada generasi muda di pesisir Pulau Jawa.

\section{Kepustakaan}

Amstrong, Karen, On the Bible, (Australia: Allen \& Unwin, 2007). Azra, Azyumardi, Jaringan Ulama Timur Tengah dan Kepulauan Nusantara Abad XVII dan XVIII: Akar Pembaruan Islam Indonesia, (Jakarta: Kencana, 2004).

Bawani, Imam, Segi-Segi Pendidikan Islam, (Surabaya: Usaha Nasional, 1997).

Barkley, Jonathan, The Transmission of Knowledge in Medieval Cairo, A Social History of Islamic Education, (New Jersey: Princeton University Press, 1992).

Bruinessen, Martin van, "Pesantren dan Tradisi Kitab Kuning Pemelihara dan Kesinambungan Tradisi Pesantren", dalam Ulumul Qur'an, (vol. III, no. 4 Tahun 1992).

${ }^{52}$ Tokoh-tokoh kunci yang berjasa besar dalam pertumbuhan madrasah di Jawa di antaranya: KH. Raden Asnawi (Kudus), KH. Hasyim Asy'ari (Jombang), KH. Ahmad Dahlan (Yogyakarta), KH. Abdul Ḥalim (Majalengka), KH. Abdul Wahab Hasbullah (Jombang), KH. Ilyas dan KH. Makșum (Tebuireng), KH. Sanusi (Sukabumi), KH. Mas Mansur (Surabaya), dan Ahmad Surkati al-Anșari (Jakarta). 
------, Kitab Kuning, Pesantren dan Tarekat, Tradisi-Tradisi Islam di Indonesia, (Bandung: Mizan, 1995).

Daulay, Haidar Putra, Historisitas dan Eksistensi Pesantren Sekolah dan Madrasah, (Yogyakarta: Tiara Wacana, 2001).

Departemen Agama Republik Indonesia, Sejarah Madrasah: Pertumbuhan, Dinamika, dan Perkembangannya di Indonesia, (Jakarta: Direktorat Jendral Kelembagaan Agama Islam Depag Republik Indonesia, 2004).

Dhofier, Zamakhsyari, The Pesantren Tradition; The Role of The Kiai in The Maintenance of Traditional Islam in Java, (Arizona: Program for Southeast Asian Studies, 1999).

-----, Tradisi Pesantren; Studi Tentang Pandangan Hidup Kiai, (Jakarta: LP3ES, 1982).

Dogde, Bayard, Muslim Education in Medieval Times, (Washington: The Middle East Institute, 1962).

Elmer H. Wilds, The Foundations of Modern Education, (New York: Rinehart \& Company, 1957).

Hasan Abd al-A'lā, al-Tarbiyah al-Islāmiyah fi al-Qarn al-Rabi' alHijri, (Cairo: Dār al-Fikr al-'Arābi, 1978).

Hurgronje, C. Snouck, Mekka in The Latter Part of 19th Century, (Leiden: E.J. Brill, 1970).

Ira M. Lapidus, A History of Islamic Society, (Cambridge: Cambridge University Press, 1988).

John L. Esposito, The Oxford Encyclopaedia of The Modern Islamic World, vol. I. (Oxford: Oxford University Press, 1995).

Joseph S. Szyliowicz, Education and Modernization in The Midle East, (London: Cornell University Press, 1973).

Kong, Yuanzhi, Muslim Tionghoa Cheng Ho: Misteri Perjalanan Muhibah di Nusantara, (Jakarta: Obor, 2005).

Leiser, Gary,"Notes on Madrasah in Medieval Islamic Society", The Muslim World, (vol. LXXVI/1986).

Lombard, Dennys, Nusa Jawa: Silang Budaya Bagian 2 (Le Carrefour Javanais), terj. Winarsih Partaningrat Arifin, dkk. (Jakarta: Gramedia, 2005).

Maksum, Madrasah, Sejarah dan Perkembangannya, (Jakarta: Logos, 1999). 
Mansur, Sejarah Syarikat Islam dan Pendidikan Bangsa, (Yogyakarta: Pustaka Pelajar, 2004).

Mas'ud, Abdurrahman, Dari Haramayn ke Nusantara; Jejak Intelektual Pesantren, (Jakarta: Kencana, 2006).

Maqdisi, George, The Rise of Colleges; Institutions of Learning in Islam and The West, (Edinburgh: Edinburgh University Press, 1981).

Ricklefs, M.C., Sejarah Indonesia Moderen 1200 - 2004, terj. Satrio Wahono dkk., (Jakarta: Serambi, 2007).

Muchtarom, Zaini, Islam Jawa dalam Perspektif Santri dan Abangan, (Jakarta: Salemba Diniyah, 2002).

Nakosteen, Mehdi, History of Islamic Origins of Western Education AD. 800 - 1350, With an Introduction to Medieval Muslim Education, (Colorado: University of Colorado Press, 1964).

Rahman, Fazlur, Islam, terj. Ahsin Mohamad, (Bandung: Pustaka, 1994).

Richard W. Bulliet, The Patricians of Nishapur, A Study in Medieval Islamic Social History, (Harvad: Harrvad University Press, 1972).

Stanton, Charles Michael, Higher Learning in Islam, Clasical Period AD. 700-1300, (Maryland: Rowman \& Littlefield Publisher, 1990).

Steenbrink, Karel, Beerapa Aspek Tentang Islam di Indonesia Abad ke-19, (Jakarta: Bulan Bintang, 1984).

Subhan, Arif, Lembaga Pendidikan Islam Indonesia Abad ke-20: Pergumulan Antara Modernisasi dan Identitas, (Jakarta: Kencana, 2012).

Syalaby, Ahmad, Sedjarah Pendidikan Islam, terj. Muchtar Jahja, dan Sanusi Latief (Jakarta: Bulan Bintang, 1973).

Tan Ta Sen, Cheng Ho: Penyebar Islam dari China ke Nusantara, (Jakarta: Penerbit Buku Kompas, 2010).

Thomas W Arnold, The Spread of Islam in The World, A History of Peaceful Preaching, (New Delhi: Goodword Books, 2001).

Yūnus, Maḥmud, Sejarah Pendidikan Islam di Indonesia, (Jakarta: Mutiara Sumber Widya, 1961).

Watt, W. Montgomerry, The Majesty That was Islam, (London: Sidwick and Jacson, 1974). 
